\title{
Silent Synapses in the Developing Rat Visual Cortex: Evidence for Postsynaptic Expression of Synaptic Plasticity
}

\author{
Simon Rumpel, Hanns Hatt, and Kurt Gottmann \\ Lehrstuhl für Zellphysiologie, Ruhr-Universität Bochum, D-44870 Bochum, Germany
}

In the developing visual cortex activity-dependent refinement of synaptic connectivity is thought to involve synaptic plasticity processes analogous to long-term potentiation (LTP). The recently described conversion of so-called silent synapses to functional ones might underlie some forms of LTP. Using wholecell recording and minimal stimulation procedures in immature pyramidal neurons, we demonstrate here the existence of functionally silent synapses, i.e., glutamatergic synapses that show only NMDA receptor-mediated transmission, in the neonatal rat visual cortex. The incidence of silent synapses strongly decreased during early postnatal development. After pairing presynaptic stimulation with postsynaptic depolarization, silent synapses were converted to functional ones in an LTP-like manner, as indicated by the long-lasting induction of AMPA receptor-mediated synaptic transmission. This conversion was dependent on the activation of NMDA receptors during the pairing protocol.
The selective activation of NMDA receptors at silent synapses could be explained presynaptically by assuming a lower glutamate concentration compared with functional ones. However, we found no differences in glutamate concentrationdependent properties of NMDA receptor-mediated PSCs, suggesting that synaptic glutamate concentration is similar in silent and functional synapses. Our results thus support a postsynaptic mechanism underlying silent synapses, i.e., that they do not contain functional AMPA receptors. Synaptic plasticity at silent synapses might be expressed postsynaptically by modification of nonfunctional AMPA receptors or rapid membrane insertion of AMPA receptors. This conversion of silent synapses to functional ones might play a major role in activity-dependent synaptic refinement during development of the visual cortex.

Key words: visual cortex; synapse development; synaptic plasticity; silent synapses; AMPA receptor; NMDA receptor; glutamate concentration
Activity-dependent refinement of synaptic connectivity during the early postnatal development of the visual cortex is thought to underlie the emergence of the adult pattern of cortical neuronal circuits (Goodman and Shatz, 1993; Singer, 1995; Katz and Shatz, 1996). The cellular and molecular mechanisms involved in the competition of presynaptic axons for their postsynaptic targets have been proposed to be analogous to synaptic plasticity phenomena such as long-term potentiation (LTP) and long-term depression (Artola and Singer, 1987; Bear et al., 1987, 1992; Tsumoto, 1992; Fox and Daw, 1993; Crair and Malenka, 1995; Kirkwood et al., 1995; Singer 1995; Katz and Shatz, 1996).

Recently, a novel mechanism leading to LTP at glutamatergic synapses, i.e., the conversion of silent synapses to functional ones, has been described in the hippocampus and in the somatosensory cortex (Isaac et al., 1995, 1997; Liao et al., 1995; Durand et al., 1996). Silent synapses exhibit exclusively NMDA receptormediated synaptic transmission and are functionally silent at the resting membrane potential because of the strong, voltagedependent $\mathrm{Mg}^{2+}$ block of NMDA receptors (McBain and Mayer, 1994). A conversion of silent synapses to functional ones can be achieved by pairing presynaptic stimulation with postsynaptic depolarization, and the conversion is dependent on the activation of NMDA receptors (Isaac et al., 1995, 1997; Liao et al., 1995; Durand et al., 1996).

\footnotetext{
Received May 4, 1998; revised Aug. 21, 1998; accepted Aug. 21, 1998.

This work was supported by Deutsche Forschungsgemeinschaft Grant SFB 509/ C1. We thank Dr. B. Ache for helpful comments on this manuscript and H. Jung and H. Bartel for excellent technical assistance.

Correspondence should be addressed to Dr. Kurt Gottmann at the above address. Copyright (C) 1998 Society for Neuroscience 0270-6474/98/188863-12\$05.00/0
}

There are two major alternative explanations regarding the molecular mechanisms underlying silent synapses (Kullmann and Siegelbaum, 1995; Malenka and Nicoll, 1997; Kullmann and Asztely, 1998). First, silent synapses might be postsynaptically silent; i.e., they might contain either nonf unctional or no AMPA receptors (Isaac et al., 1995; Liao et al., 1995; Durand et al., 1996). Second, silent synapses might be presynaptically silent (Kimura et al., 1997); i.e., they might release much less glutamate than functional synapses, or they might not release glutamate at all. Because NMDA receptors exhibit a much higher affinity to glutamate than do AMPA receptors (Patneau and Mayer, 1990; Hestrin, 1992), NMDA receptors might be activated by low concentrations of glutamate that are not sufficient to elicit a detectable AMPA receptor-mediated PSC. Spillover of glutamate from a functional synapse adjacent to a silent synapse releasing no glutamate might also provide a low concentration of glutamate that would activate only NMDA receptors (Kullmann et al., 1996; Asztely et al., 1997; Barbour and Häusser, 1997; Kullmann and Asztely, 1998).

In the present study, we demonstrate the existence of silent synapses in the neonatal rat visual cortex. We further address whether the glutamate concentration is lower at silent synapses compared with functional ones by comparing the rise times of NMDA PSCs, which strongly depend on glutamate concentration (Clements and Westbrook, 1991). Furthermore we studied glutamate concentration-dependent block of NMDA PSCs by the rapidly unbinding NMDA receptor antagonist D-aminoadipate (D-AA) (Clements et al., 1992; Clements, 1996). We found no difference between silent and functional synapses in these glutamate concentration-dependent properties of NMDA PSCs. Our 
results do not support the hypothesis that the glutamate concentration is lower at silent synapses and are thus consistent with the idea that a postsynaptic mechanism underlies synaptic plasticity at silent synapses.

\section{MATERIALS AND METHODS}

Electrophysiology. Coronal slices ( $300 \mu \mathrm{m}$ thick) of the visual cortex from 3- to 11-d-old Wistar rats were cut with a vibratome. Slices were incubated in artificial CSF (in mM: $125 \mathrm{NaCl}, 3 \mathrm{KCl}, 1.25 \mathrm{NaH}_{2} \mathrm{PO}_{4}, 25$ $\mathrm{NaHCO}_{3}, 20 \mathrm{D}$-glucose, $2.5 \mathrm{CaCl}_{2}$, and $1.5 \mathrm{MgCl}_{2}$, saturated with $95 \%$ $\mathrm{O}_{2} / 5 \% \mathrm{CO}_{2}, \mathrm{pH} 7.3$ ) and allowed to recover for at least $1 \mathrm{hr}$ at room temperature. All recordings were made at $28-30^{\circ} \mathrm{C}$ in a submerged slice chamber perfused with artificial CSF with added picrotoxin $(100 \mu \mathrm{M})$.

Whole-cell patch-clamp recordings were obtained in layers V/VI of the visual cortex using the blind-patch technique (Blanton et al., 1989). Recording electrodes (7-10 M $\Omega$ ) were filled with intracellular solution I (in mM: $135 \mathrm{~K}$-gluconate, $20 \mathrm{KCl}, 2 \mathrm{MgCl}_{2}, 10 \mathrm{HEPES}, 1$ EGTA, 4 $\mathrm{Na}_{2}-\mathrm{ATP}$, and $0.5 \mathrm{Na}_{2}-\mathrm{GTP}$, and $0.3 \%$ Lucifer yellow, adjusted to $\mathrm{pH} 7.3$ with $\mathrm{KOH}$ ) in current-clamp experiments. In voltage-clamp experiments intracellular solution II (in mM: $135 \mathrm{CsCl}, 20$ TEA-Cl, $2 \mathrm{MgCl}_{2}, 10$ HEPES, $4 \mathrm{Na}_{2}$-ATP, $0.5 \mathrm{Na}_{2}$-GTP, and 1 or 10 EGTA, adjusted to $\mathrm{pH}$ 7.3 with $\mathrm{CsOH}$ ) was used. In experiments designed to investigate synaptic plasticity, intracellular solution II contained $1 \mathrm{mM}$ EGTA, otherwise $10 \mathrm{~mm}$. PSCs were evoked at a stimulation frequency of $0.2 \mathrm{~Hz}$ with a glass monopolar electrode placed in the visual cortex in different layers within $100-800 \mu \mathrm{m}$ of the recording electrode. The vast majority of synaptic responses were evoked by stimulation in layers V/VI. The stimulation frequency was not changed during the experiments. The input resistance (1-0.5 G $\Omega$ ) was continuously monitored by delivering a voltage step command, and cells were discarded when it changed by $>20 \%$. Recordings were made using a HEKA (Lambrecht/Pfalz, Germany) EPC-7 patch-clamp amplifier, filtered at $3 \mathrm{kHz}$, and sampled at 20 $\mathrm{kHz}(-80 \mathrm{mV}$ holding potential) or $2 \mathrm{kHz}(+40 \mathrm{mV}$ holding potential). Sampling was done with a TL-1 interface using pClamp 5.5.1 Software (Axon Instruments, Foster City, CA), and data were stored on computer disk.

Data analysis. Off-line analysis of PSCs was done using AUTESP software (H. Zucker, Max-Planck-Institut für Psychatrie, Martinsried, Germany). Briefly, response amplitudes at $-80 \mathrm{mV}$ holding potential were measured as the difference between the amplitude during a $0.8 \mathrm{msec}$ window including the peak of the PSC and the amplitude during a window $2 \mathrm{msec}$ before the stimulus. To avoid contamination of measurements by the stimulus artifact, averaged traces of visually identified failures were subtracted before analysis. Noise amplitudes were measured as the difference between the amplitude during the window $2 \mathrm{msec}$ before the stimulus and a third window $6 \mathrm{msec}$ before the stimulus. PSC amplitudes at $+40 \mathrm{mV}$ holding potential were measured analogously, but subtraction of failures was omitted, and the size of the windows used was $8 \mathrm{msec}$. To estimate the amplitude of the NMDA receptor-mediated component of the PSC, the window was positioned $30 \mathrm{msec}$ after the stimulus, assuming complete decline of the AMPA receptor-mediated component within $30 \mathrm{msec}$

For each trace the SD of the baseline noise before the stimulus was calculated. Response amplitudes smaller than twofold SD of the noise were considered failures. In the experiments designed to estimate the proportion of silent synapses by comparing failure rates at -80 and +40 $\mathrm{mV}$ holding potential the fraction of silent synapses was calculated according to the method of $\mathrm{Wu}$ et al. (1996). Data are expressed as mean \pm SEM. For statistical tests of significance, a two-tailed Student's $t$ test was applied. Statistical comparison of response or noise amplitude distributions was done using a Kolmogorov-Smirnov test.

\section{RESULTS}

\section{Silent synapses in the neonatal visual cortex}

To study silent synapses in the developing rat visual cortex, whole-cell recordings were obtained from layer V/VI neurons in acute brain slices from rat pups [postnatal day 3 (P3)-P12] using the blind-patch technique. To characterize the recorded neurons morphologically, 48 cells were filled with Lucifer yellow. Most neurons $(88 \%)$ had the morphology typical of immature pyramidal neurons (Kasper et al., 1994b; Fig. 1). At P $>5$ the pattern of action potential discharge in these immature pyramidal cells was

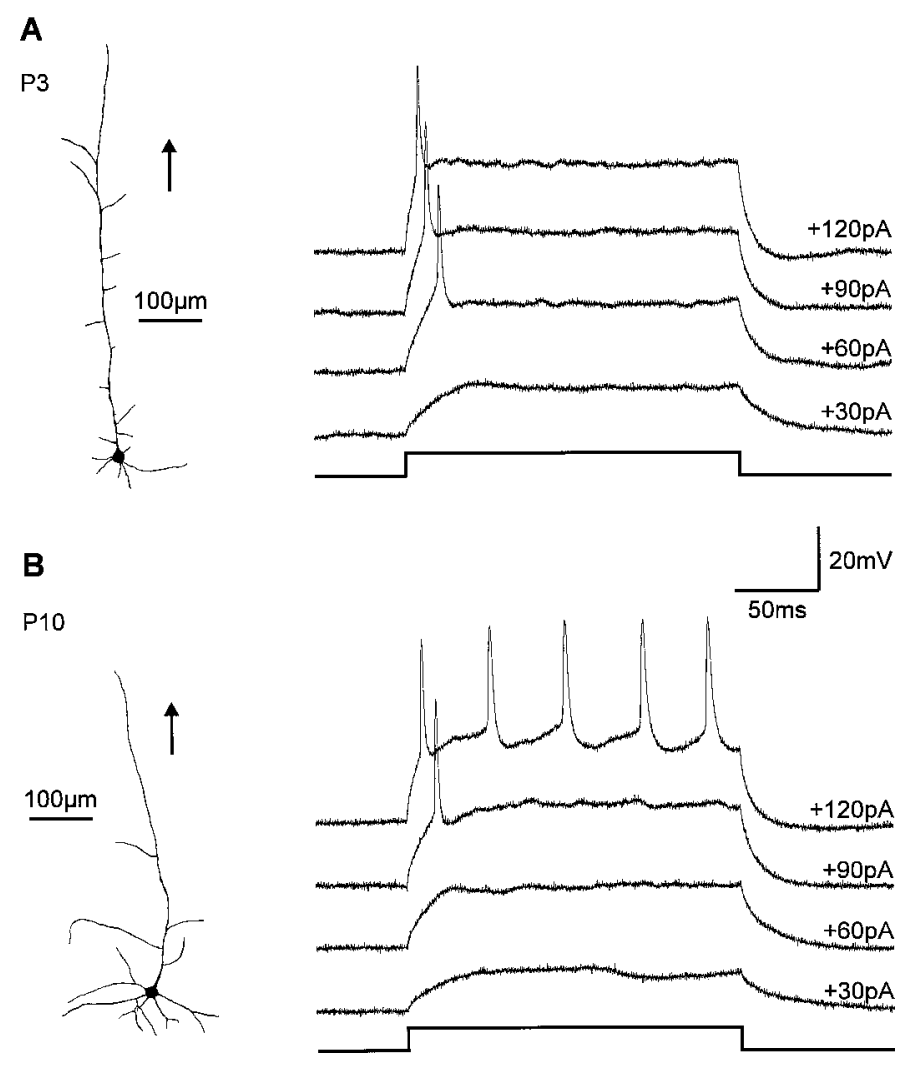

Figure 1. Morphology and action potential discharge pattern of immature pyramidal neurons in layers V/VI. $A$, Reconstruction of a Lucifer yellow-filled pyramidal neuron at P3. Orientation to the pial surface is indicated by the arrow. At P3 pyramidal neurons typically respond with a single action potential to current injection. Amplitude of injected current is indicated at the corresponding membrane voltage record. $B$, Reconstruction of a Lucifer yellow-filled pyramidal neuron at P10. These more differentiated pyramidal neurons showed a train of action potentials after current injection.

similar to that in nonbursting cells (Kasper et al., 1994a). Pyramidal neurons in slices obtained from younger animals (P3-P4) exhibited a pattern of action potential firing that was even more immature, typically showing only one action potential after current injection (Fig. 1).

To examine the properties of glutamatergic synapses, PSCs were evoked by intracortical extracellular stimulation using a patch pipette that was located within $100-800 \mu \mathrm{m}$ of the recorded neuron. $\mathrm{GABA}_{\mathrm{A}}$ receptor-mediated PSCs were blocked by addition of $100 \mu \mathrm{M}$ picrotoxin to the extracellular solution. In the initial experiments, a small stimulation strength near minimal stimulation (Stevens and Wang, 1994) was used. At $-80 \mathrm{mV}$ holding potential and in the presence of $1.5 \mathrm{~mm} \mathrm{Mg}^{2+}$, PSCs were completely and reversibly blocked $(94 \pm 1 \%$ of peak amplitude; $n=5)$ by the non-NMDA receptor antagonist DNQX $(10 \mu \mathrm{M})$, demonstrating that they were mediated by AMPA receptors. At a holding potential of $+40 \mathrm{mV}$ the PSCs were dominated by NMDA receptor-mediated components, as shown by reversible blockade $(85 \pm 4 \%$ of peak amplitude; $n=4)$ by the NMDA receptor antagonist D-AP-5 $(25 \mu \mathrm{M})$. In the presence of D-AP-5 a small, rapidly declining AMPA receptor-mediated component remained at $+40 \mathrm{mV}$ holding potential. However, $30 \mathrm{msec}$ after the stimulus, the PSCs at $+40 \mathrm{mV}$ holding potential were exclusively mediated by NMDA receptors as demonstrated by the complete blockade $(97 \pm 1 \%)$ by D-AP-5. 


\section{A}

a $-80 \mathrm{mV}$ Holding Potential

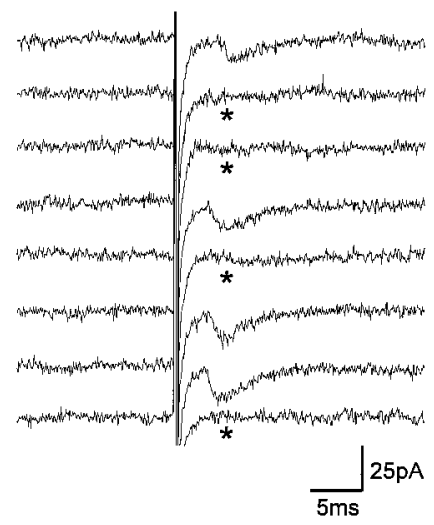

B

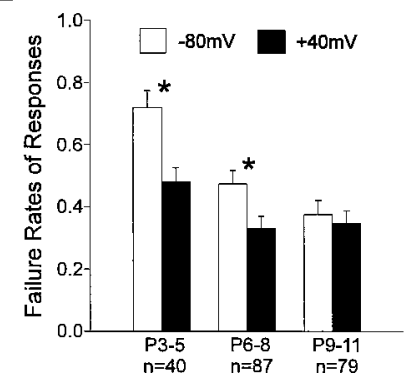

b $+40 \mathrm{mV}$ Holding Potential

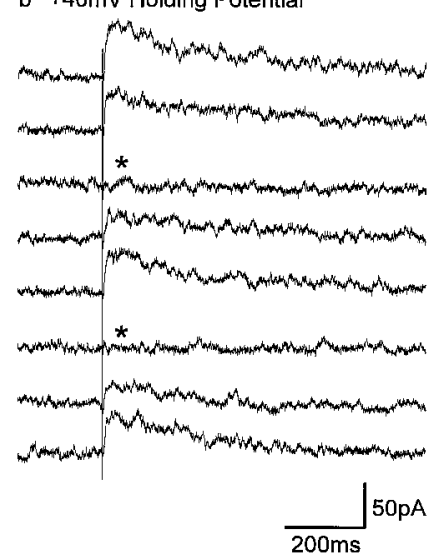

C

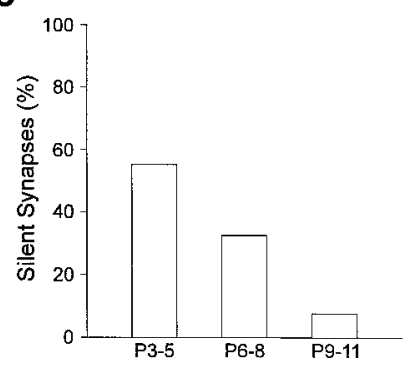

Figure 2. Different failure rates of glutamatergic PSCs at hyperpolarized and depolarized membrane potentials indicate the existence of silent synapses. $A$, PSCs evoked by intracortical stimulation at $-80 \mathrm{mV}$ holding potential $(a)$ and at $+40 \mathrm{mV}$ holding potential $(b)$ in the presence of 1.5 $\mathrm{mm} \mathrm{Mg}^{2+}$. At $+40 \mathrm{mV}$ holding potential, PSCs are dominated by an NMDA receptor-mediated component, which is blocked by $\mathrm{Mg}^{2+}$ at -80 $\mathrm{mV}$ holding potential, leading to purely AMPA receptor-mediated PSCs. Failures are indicated by asterisks. Note the reduced failure rate after changing the holding potential to $+40 \mathrm{mV}$. $B$, Mean failure rates at -80 $\mathrm{mV}$ holding potential (open bars) and at $+40 \mathrm{mV}$ holding potential (filled bars) at different stages of early postnatal development. Postnatal age (P) and number of experiments $(n)$ are indicated below the bars. Significant differences in failure rates are indicated by asterisks. Error bars represent SEM. Note the large difference in failure rates at P3-P5 that disappeared during postnatal development. $C$, Percentage of silent synapses calculated from the mean failure rates at $-80 \mathrm{mV}$ holding potential and at $+40 \mathrm{mV}$ holding potential according to $\mathrm{Wu}$ et al. (1996) (see Materials and Methods).

With minimal stimulation a small number of synapses are activated, and synaptic failures are observed in addition to PSCs (Fig. 2A; Malinow 1991; Stevens and Wang, 1994). Activation of silent synapses in the presence of $\mathrm{Mg}^{2+}$ results in failures at hyperpolarized membrane potential and in NMDA PSCs, in addition to failures, at depolarized membrane potential, because silent synapses exhibit only NMDA receptor-mediated synaptic transmission (Isaac et al., 1995, 1997; Liao et al., 1995; Durand et al., 1996; Wu et al., 1996). Thus, silent synapses are indicated by a significant difference in failure rates at hyperpolarized and depolarized membrane potentials in the presence of $\mathrm{Mg}^{2+}$. Furthermore, the incidence of silent synapses can be estimated from this difference in failure rates (Liao et al., 1995; Wu et al., 1996; Isaac et al., 1997), assuming that the average release probability is similar at functional and silent synapses. At P3-P5 the mean failure rate at $+40 \mathrm{mV}$ holding potential in the presence of 1.5 $\mathrm{mm} \mathrm{Mg}^{2+}$ was $0.48 \pm 0.05$, whereas the mean failure rate at -80

$\mathrm{mV}$ holding potential was significantly $(p<0.01)$ higher $(0.72 \pm$ $0.06)$ (Fig. $2 B$ ). From these data the percentage of silent synapses was calculated to be $55 \%$ (Fig. $2 C$ ). During the first postnatal week the mean failure rate at $-80 \mathrm{mV}$ membrane potential significantly $(p<0.01)$ decreased, whereas the mean failure rate at $+40 \mathrm{mV}$ membrane potential did not change significantly. At P9-P11 no significant difference in mean failure rates $(-80 \mathrm{mV}$, $0.38 \pm 0.04 ;+40 \mathrm{mV}, 0.35 \pm 0.04$ ) was observed, suggesting a strong developmental decline in the incidence of silent synapses. The mean amplitude of AMPA PSCs (P3-P4, $15 \pm 3$ pA; P9$\mathrm{P} 11,27 \pm 3$ at $-80 \mathrm{mV}$ holding potential) and that of PSCs recorded at $+40 \mathrm{mV}$ holding potential $(\mathrm{P} 3-\mathrm{P} 4,26 \pm 3 \mathrm{pA}$; P9-P11, $28 \pm 3$ pA) did not change significantly. Our results suggest that silent synapses are present in the neonatal visual cortex and that their incidence strongly decreases during early postnatal development, similar to the developing hippocampus (Durand et al., 1996) and the neonatal somatosensory cortex (Isaac et al., 1997).

To demonstrate the existence of silent synapses more directly, stimulation strength was reduced until no AMPA PSCs were observed for $10 \mathrm{~min}$ (112 stimuli) at $-80 \mathrm{mV}$ holding potential in the presence of $1.5 \mathrm{~mm} \mathrm{Mg}^{2+}$ (Fig. $\left.3 A, B\right)$. Accordingly, no significant difference (Kolmogorov-Smirnov test) was observed between the amplitude distribution of the recording noise and the distribution of response amplitudes (Fig. 3C). However, after changing the holding potential to $+40 \mathrm{mV}$ and stimulating at the same strength and rate $(0.2 \mathrm{~Hz})$, in addition to failures, NMDA PSCs were frequently observed. As is typical for silent synapses, only NMDA receptor-mediated synaptic transmission was observed. The released glutamate failed to activate AMPA receptors.

\section{NMDA receptor-dependent conversion of silent synapses to functional synapses}

Conversion of silent synapses to functional synapses using a pairing protocol that consisted of postsynaptic depolarization and presynaptic stimulation has been described (Isaac et al., 1995, 1997; Liao et al., 1995; Durand et al., 1996). To address whether such a conversion can also occur in the developing visual cortex, we used a similar pairing protocol. First, the stimulation strength was reduced to a failure rate $>90 \%$ at $-80 \mathrm{mV}$ holding potential in the presence of $\mathrm{Mg}^{2+}$ (Fig. 4A-C). After changing the holding potential to $+40 \mathrm{mV}$ to demonstrate the presence of NMDA PSCs, the postsynaptic neuron was depolarized to $-10 \mathrm{mV}$ for 4 min (48 stimuli), and presynaptic stimulation was continued at the same frequency $(0.2 \mathrm{~Hz})$ to prevent any changes in axon excitability. Within a few minutes after returning to $-80 \mathrm{mV}$ holding potential, the failure rate was strongly reduced, and PSCs were frequently detected. In four of seven cells, induction of functional synapses was indicated by a significant (Kolmogorov-Smirnov test, $p<0.01)$ difference in the distributions of response amplitudes before and 20-30 min after the pairing protocol (Fig. $4 D, E)$. The PSCs induced by the pairing protocol were completely blocked by DNQX $(10 \mu \mathrm{M} ; n=2)$ and thus mediated by AMPA receptors. In the remaining three cells no change in the failure rate at $-80 \mathrm{mV}$ holding potential and no significant change in the distribution of response amplitudes was observed after the pairing protocol. In the developing hippocampus, NMDA receptor activation during the pairing protocol is necessary for conversion of silent synapses to functional synapses (Isaac et al., 1995; Durand et al., 1996). To examine this point, we blocked NMDA receptors by D-AP-5 $(25 \mu \mathrm{M})$ during the pairing 
A

Holding Potential

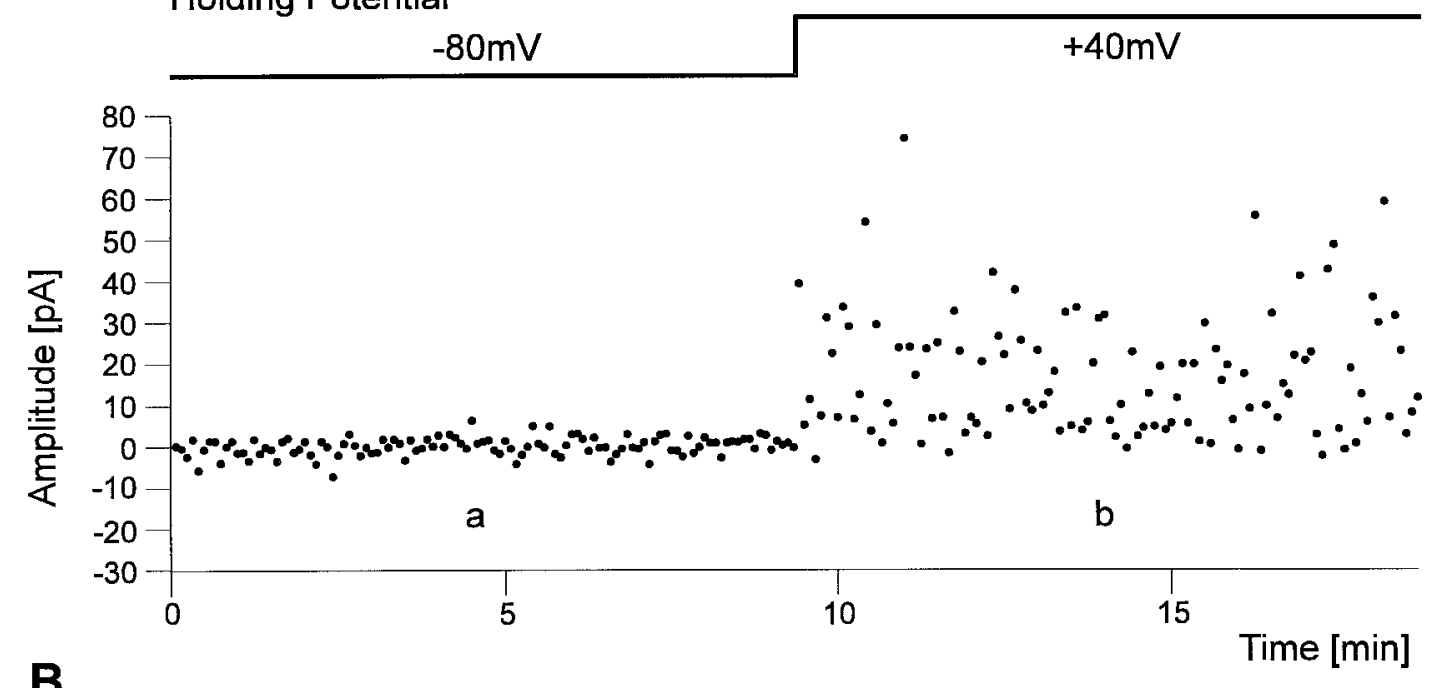

B

a
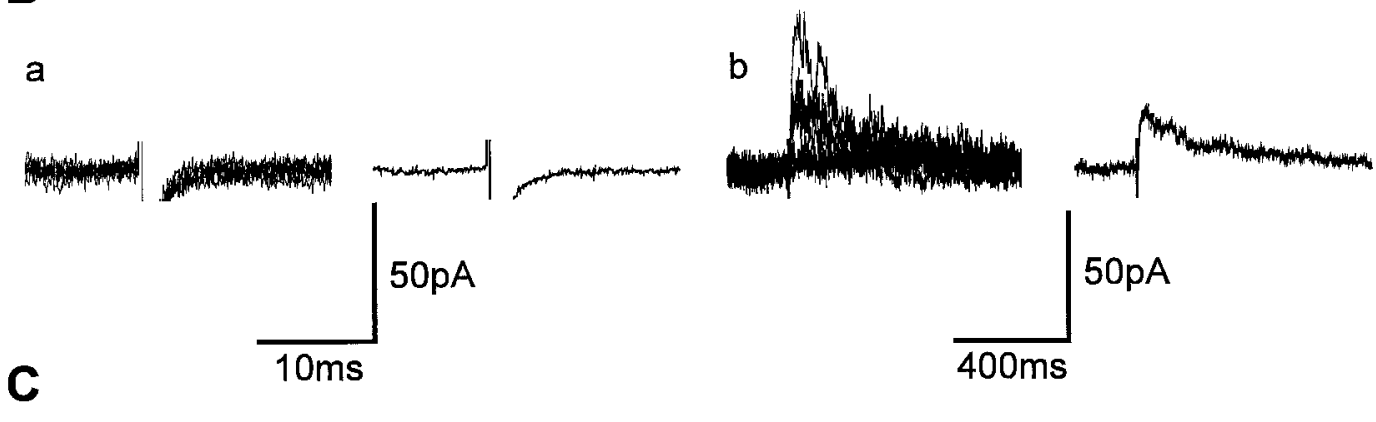

a

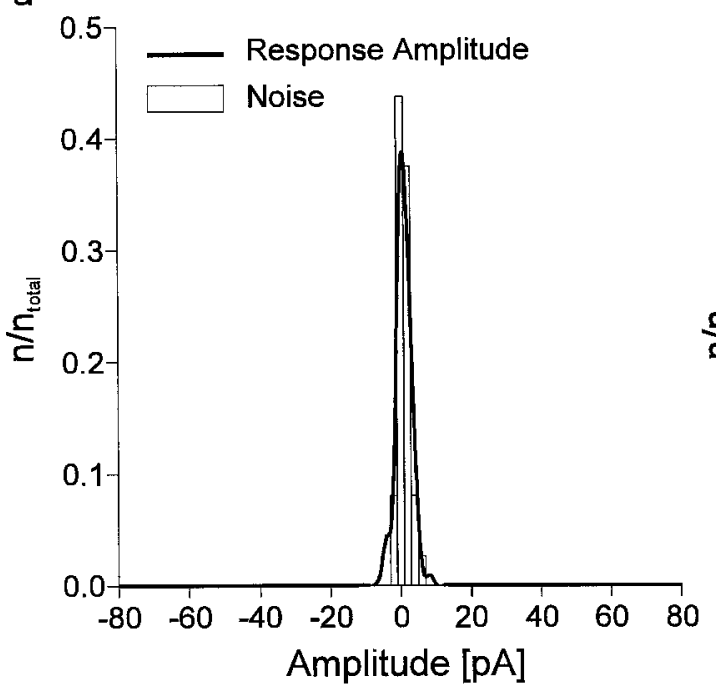

b

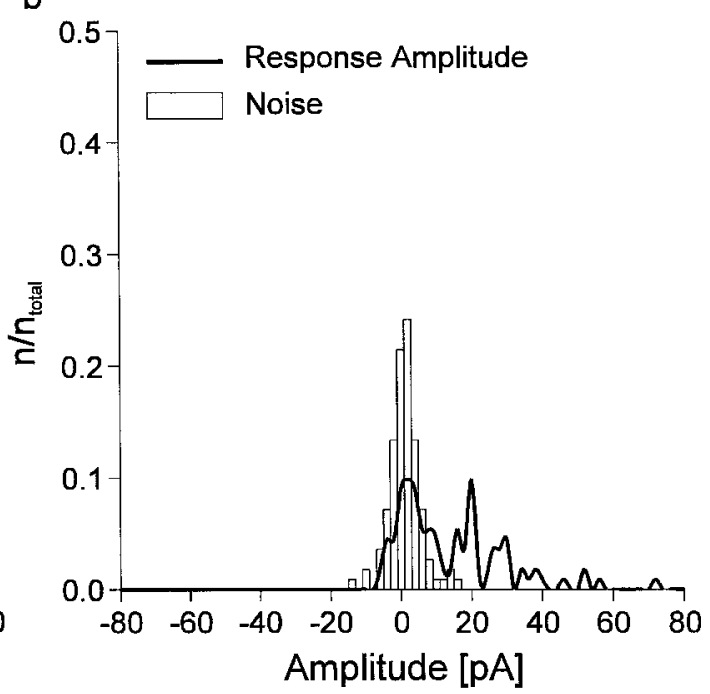

Figure 3. Example of a silent synapse at $\mathrm{P} 4$ showing exclusively NMDA receptor-mediated synaptic transmission. $A$, Individual response amplitudes recorded during the experiment at $-80 \mathrm{mV}$ holding potential and at $+40 \mathrm{mV}$ holding potential. $B$, Eight superimposed individual traces (left) and average currents (right) from the experiment shown in $A$ at $-80 \mathrm{mV}$ holding potential $(a)$ and at $+40 \mathrm{mV}$ holding potential $(b)$. Note the absence of AMPA receptor-mediated PSCs. C, Amplitude histograms (bin width, $2 \mathrm{pA}$ ) of response amplitudes (thick line) and noise amplitudes (open bars) at -80 $\mathrm{mV}$ holding potential $(a)$ and at $+40 \mathrm{mV}$ holding potential $(b)$ from the experiment shown in $A$.

protocol. This treatment abolished NMDA PSCs at $+40 \mathrm{mV}$ holding potential (Fig. 5). In all eight cells tested, no change in the failure rate at $-80 \mathrm{mV}$ holding potential and no significant change in the distribution of response amplitudes was found after the pairing protocol in the presence of D-AP-5.
A summary of the experiments involving a pairing protocol is shown in Figure 6. For experiments in which the pairing protocol was performed in the absence of D-AP-5, only those cells were included that showed a significant change in the distribution of response amplitudes at $-80 \mathrm{mV}$ holding potential after the pair- 
A

\section{Holding Potential}

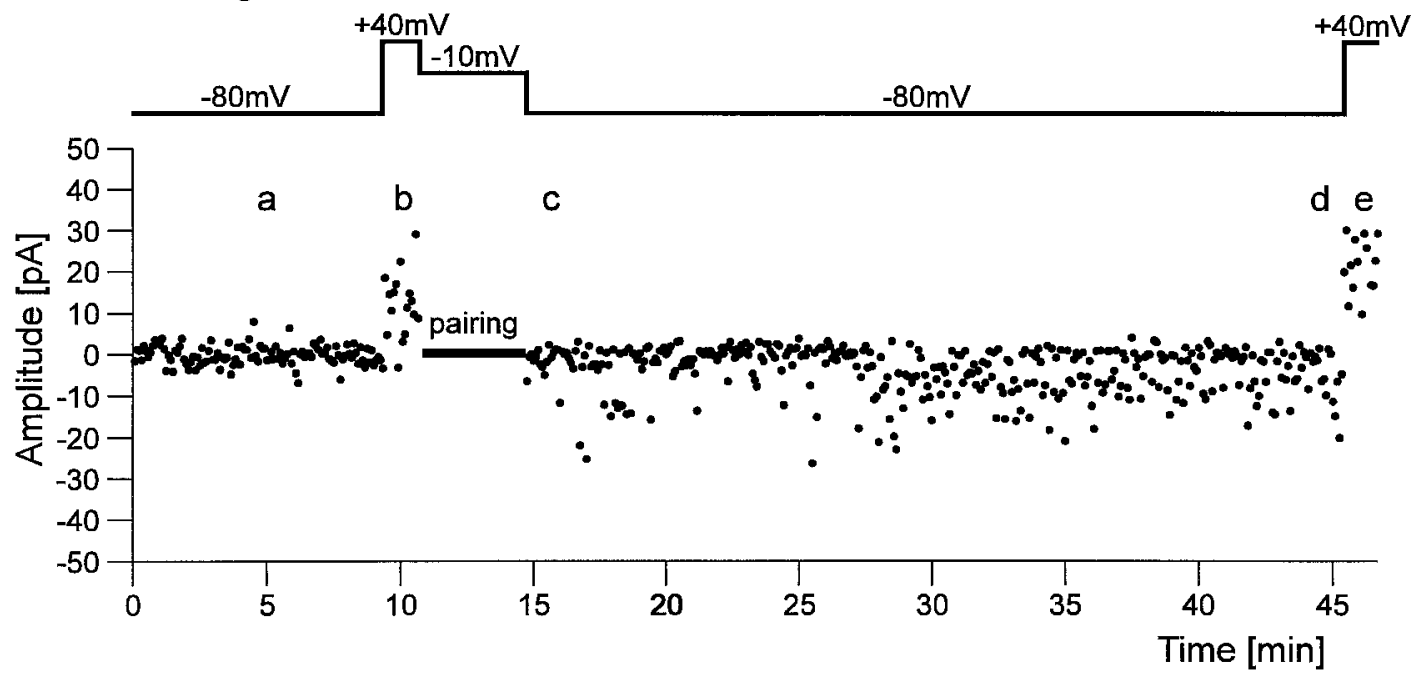

B

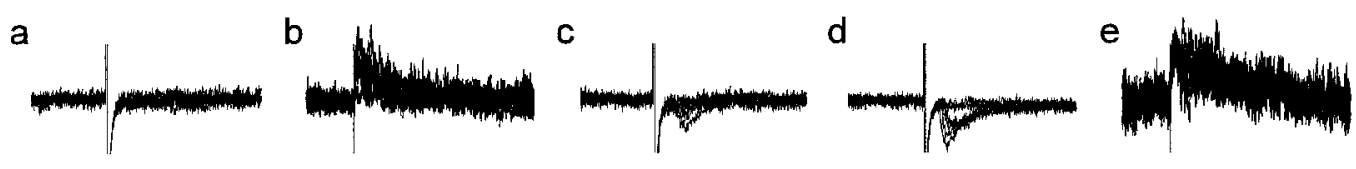

C

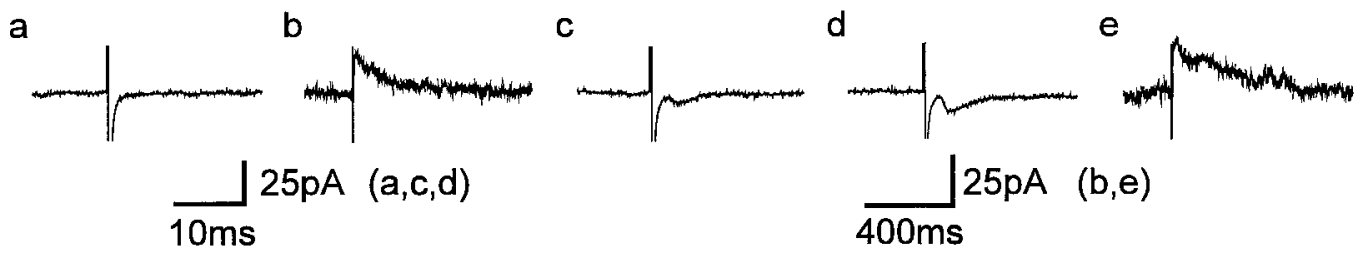

D

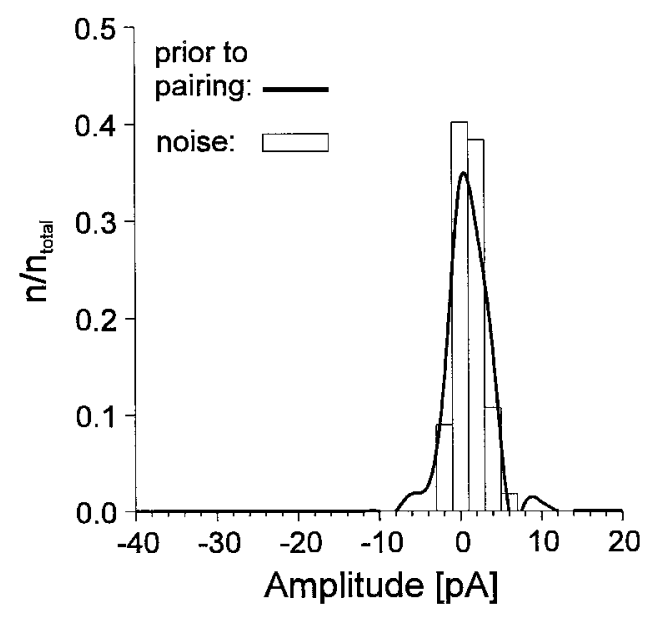

E

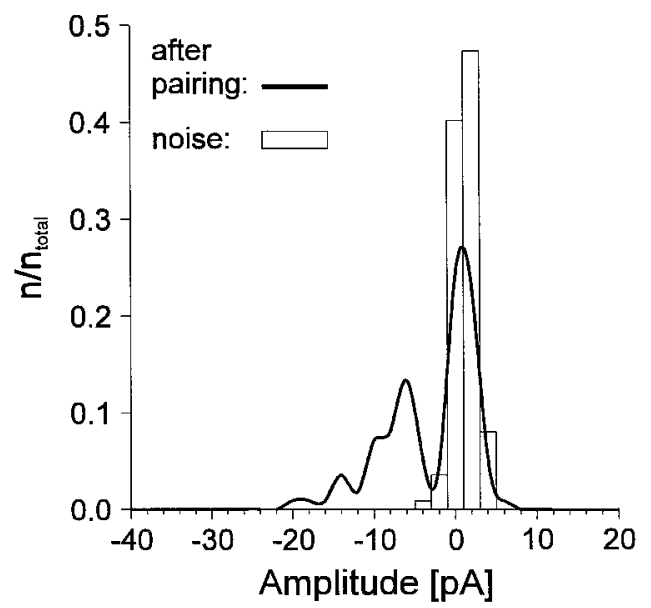

Figure 4. Conversion of silent synapses in functional ones by a pairing protocol. $A$, Individual response amplitudes recorded during the course of the experiment. Response amplitudes were recorded at $-80 \mathrm{mV}$ holding potential and at $+40 \mathrm{mV}$ holding potential before and after pairing of presynaptic stimulation and postsynaptic depolarization. Note the appearance of AMPA PSCs at $-80 \mathrm{mV}$ holding potential after the pairing protocol. $B$, Eight superimposed individual current traces recorded at the positions indicated in $A$ at $-80 \mathrm{mV}$ holding potential $(a, c, d)$ and at $+40 \mathrm{mV}$ holding potential $(b, e) . C$, Average currents corresponding to the individual traces shown in $B$. D, Amplitude histogram (bin width, $2 \mathrm{pA})$ of response amplitudes $($ thick line) and noise amplitudes (open bars) at $-80 \mathrm{mV}$ holding potential before pairing from the experiment shown in $A$. E, Amplitude histogram (bin width, $2 \mathrm{pA}$ ) of response amplitudes (thick line) and noise amplitudes (open bars) at $-80 \mathrm{mV}$ holding potential $20-30$ min after pairing from the experiment shown in $A$. 
A

Holding Potential
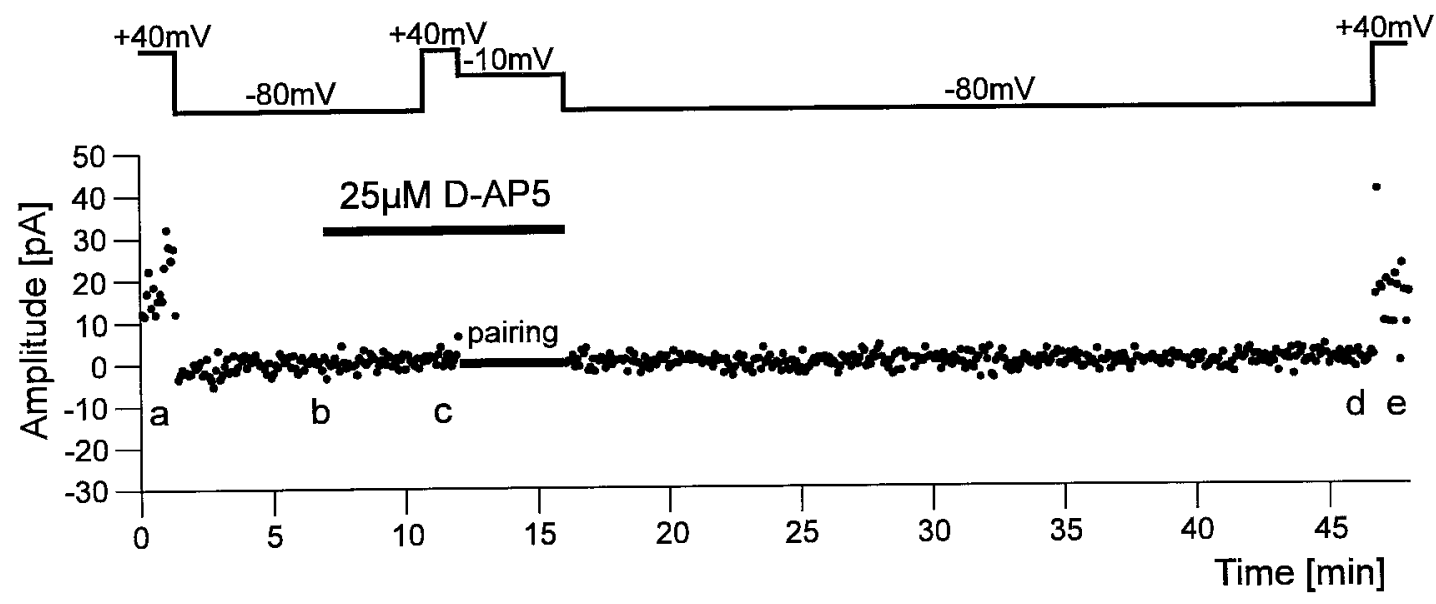

B

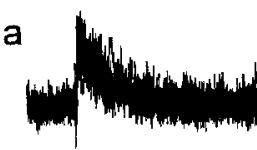

b

C
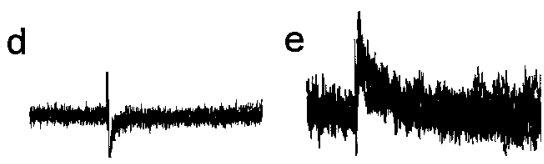

C

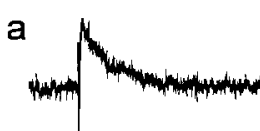

b

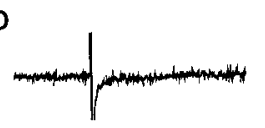

C

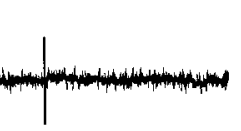

d
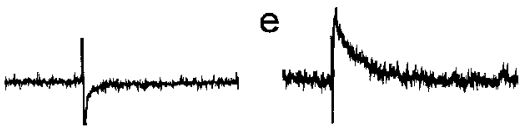

$\int_{400 \mathrm{~ms}} 25 \mathrm{pA} \quad(\mathrm{a}, \mathrm{c}, \mathrm{e})$

$\underset{10 \mathrm{~ms}}{\operatorname{25pA}}(\mathrm{b}, \mathrm{d})$

D

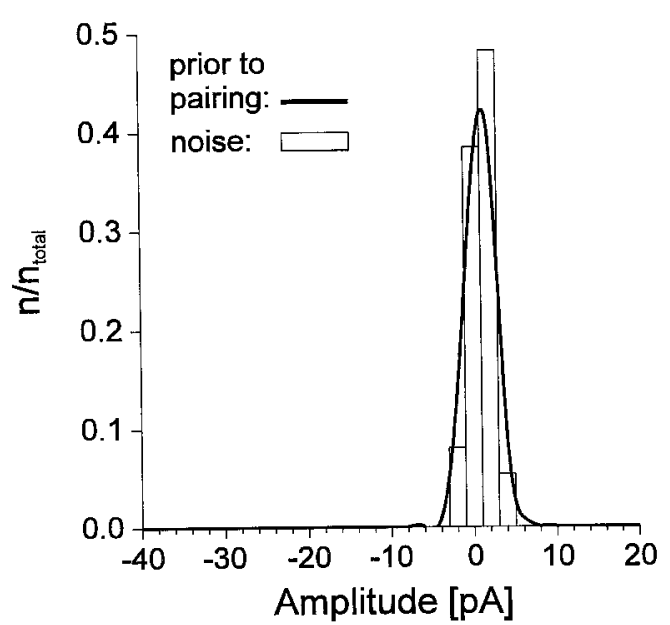

$\mathbf{E}$

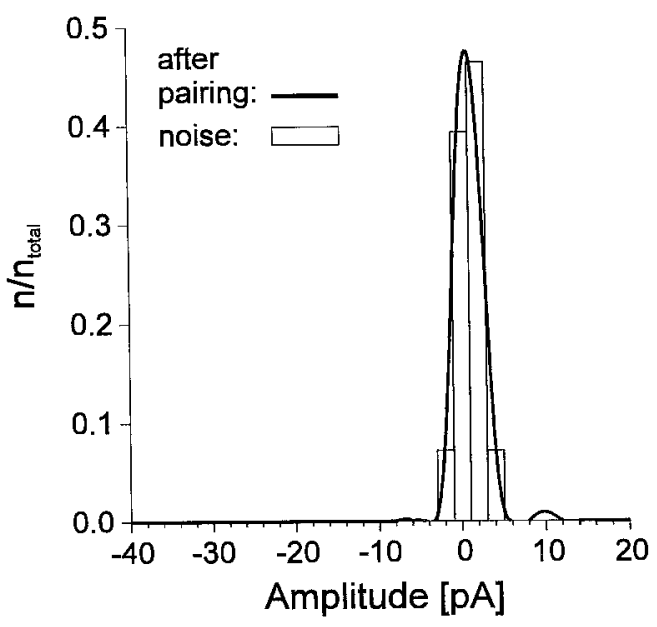

Figure 5. Conversion of silent synapses in functional ones is dependent on NMDA receptor activation. $A$, Individual response amplitudes recorded during the course of the experiment. D-AP-5 was applied after recording response amplitudes at $+40 \mathrm{mV}$ and at $-80 \mathrm{mV}$ holding potential. Blockade of NMDA receptors was confirmed by recording response amplitudes at $+40 \mathrm{mV}$ holding potential before pairing. After pairing no AMPA PSCs were observed at $-80 \mathrm{mV}$ holding potential. $B$, Eight superimposed individual current traces recorded at the positions indicated in $A$ at $+40 \mathrm{mV}$ holding potential $(a, c, e)$ and at $-80 \mathrm{mV}$ holding potential $(b, d)$. $C$, Average currents corresponding to the individual traces shown in $B$. $D$, Amplitude histogram (bin width, $2 \mathrm{pA}$ ) of response amplitudes (thick line) and noise amplitudes (open bars) at $-80 \mathrm{mV}$ holding potential before pairing from the experiment shown in $A$. E, Amplitude histogram (bin width, $2 \mathrm{pA}$ ) of response amplitudes (thick line) and noise amplitudes (open bars) at $-80 \mathrm{mV}$ holding potential 20-30 min after pairing from the experiment shown in $A$. 
Pairing

A

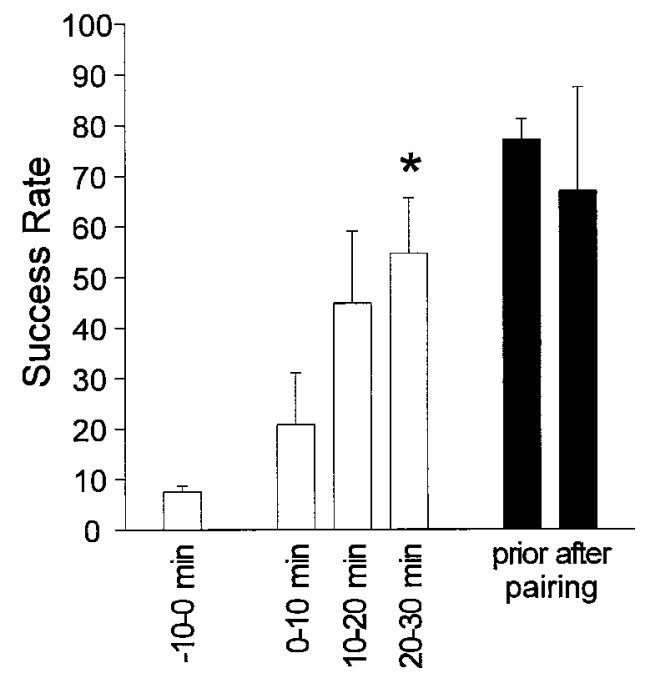

C

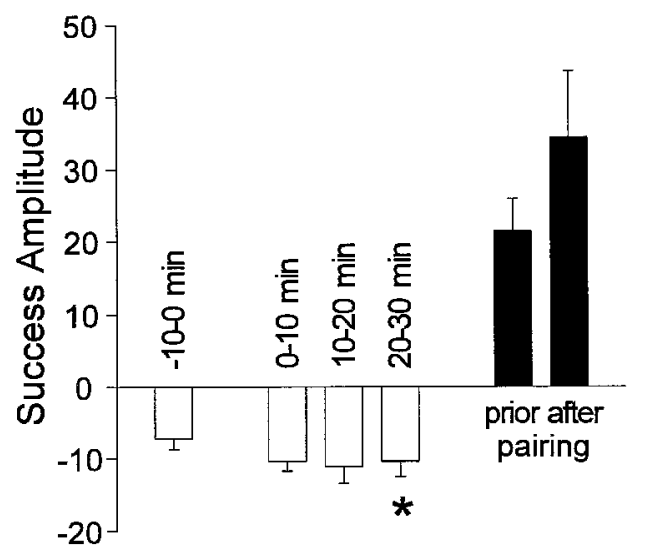

AMPA receptor-mediated PSCs
Pairing+D-AP5

B

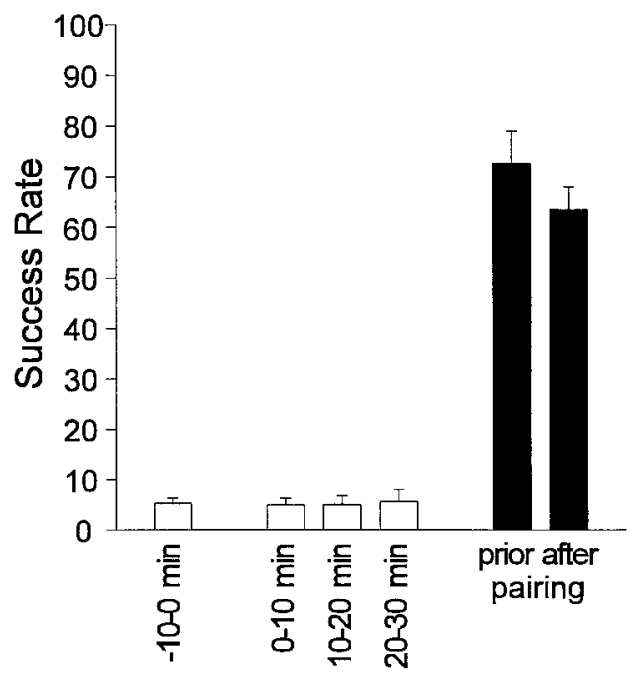

D

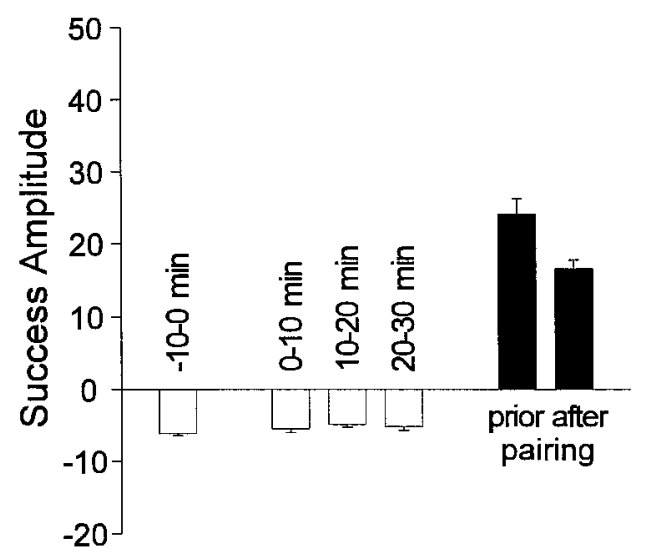

NMDA receptor-mediated PSCs

Figure 6. Summary of experiments demonstrating NMDA receptor-dependent conversion of silent synapses in functional ones. $A$, Mean success rates at $-80 \mathrm{mV}$ holding potential (open bars) before $(-10-0 \mathrm{~min})$ and $0-10 \mathrm{~min}, 10-20 \mathrm{~min}$, and $20-30 \mathrm{~min}$ after pairing. The asterisk indicates a significant increase in success rate of AMPA PSCs after pairing. Filled bars represent mean success rates at $+40 \mathrm{mV}$ holding potential before and after pairing. Error bars represent SEM. B, Mean success rates at $-80 \mathrm{mV}$ holding potential (open bars) before and after pairing in the presence of $25 \mu \mathrm{M}$ D-AP-5. No increase in mean success rate of AMPA PSCs was observed. Filled bars represent mean success rates at $+40 \mathrm{mV}$ holding potential before and after pairing in the presence of D-AP-5. C, Mean success amplitudes at $-80 \mathrm{mV}$ holding potential (open bars) before and after pairing. The asterisk indicates a significant increase in mean success amplitude of AMPA PSCs after pairing. Filled bars represent mean success amplitudes at $+40 \mathrm{mV}$ holding potential before and after pairing. The slight increase was not significant. Error bars represent SEM. $D$, Mean success amplitudes at $-80 \mathrm{mV}$ holding potential (open bars) before and after pairing in the presence of $25 \mu \mathrm{M}$ D-AP-5. No increase in mean success amplitude of AMPA PSCs was observed. Filled bars represent mean success rates at $+40 \mathrm{mV}$ holding potential before and after pairing in the presence of D-AP-5.

ing protocol. In these four cells the mean success rate $(1-$ failure rate) at $-80 \mathrm{mV}$ holding potential was significantly $(p<0.01)$ increased from $0.07 \pm 0.01$ to $0.54 \pm 0.1120-30 \mathrm{~min}$ after the end of the pairing protocol. The mean success rate at $+40 \mathrm{mV}$ holding potential did not change significantly $(0.77 \pm 0.04$ before pairing and $0.67 \pm 0.21$ after pairing). At $-80 \mathrm{mV}$ holding potential a slight increase $(p<0.05)$ occurred in the mean success amplitudes $(7 \pm 2 \mathrm{pA}$ before pairing and $10 \pm 2 \mathrm{pA} 20-30$ min after pairing), whereas at $+40 \mathrm{mV}$ holding potential no significant change occurred $(21 \pm 4 \mathrm{pA}$ before pairing and $34 \pm$ $9 \mathrm{pA}$ after pairing) during the experiments. This increase can be explained solely by the fact that with a higher number of functional synapses the probability that two or more quanta are released synchronously increases (experiment, 144\% increase; calculated, $139 \%$ increase). However, an increase in quantal size in addition to an increase in the number of release sites cannot be excluded. In the presence of D-AP-5 during the pairing protocol the increase in mean success rate at $-80 \mathrm{mV}$ holding potential was blocked $(0.05 \pm 0.01$ before pairing and $0.06 \pm 0.0220-30$ min after pairing). In conclusion, our results are consistent with the induction of functional transmission by AMPA receptors at hyperpolarized membrane potentials at previously silent synapses 
after pairing of postsynaptic depolarization and presynaptic stimulation. Functional synapse induction required the activation of NMDA receptors.

\section{Comparison of glutamate concentration-dependent properties of NMDA PSCs at silent and functional synapses}

There are two alternative ways to explain why silent synapses are nonf unctional at hyperpolarized membrane potential (Kullmann and Siegelbaum, 1995; Malenka and Nicoll, 1997; Kullmann and Asztely, 1998). First, silent synapses might contain only functional NMDA receptors. AMPA receptors would be either nonfunctional or not present in the postsynaptic membrane. Because of the strong voltage-dependent $\mathrm{Mg}^{2+}$ block of NMDA receptors, such synapses would be silent at hyperpolarized membrane potential (Isaac et al., 1995; Liao et al., 1995; Durand et al., 1996; Wu et al., 1996). Alternatively, the glutamate concentration in the synaptic cleft might be smaller in silent synapses. Because NMDA receptors have a higher affinity for glutamate than do AMPA receptors, a low concentration of glutamate might selectively activate NMDA receptors (Kullmann et al., 1996; Asztely et al., 1997; Malenka and Nicoll, 1997). Thus, these alternative explanations differ markedly relative to the postulated concentration of glutamate in the synaptic cleft.

To address the mechanisms underlying silent synapses, we attempted to compare the glutamate concentrations in silent and functional synapses. First, we examined whether the mean rise time (10-90\%) of NMDA PSCs is dependent on the percentage of silent synapses present in a given recording (Fig. 7). As demonstrated in outside-out patches (Clements and Westbrook, 1991), the rise time of NMDA receptor-mediated currents is strongly dependent on the glutamate concentration (at concentrations $\leq 50 \mu \mathrm{M}$ ). The percentage of silent synapses was estimated for each recording from the failure rates (112 stimuli at 0.2 $\mathrm{Hz}$ ) obtained at $-80 \mathrm{mV}$ and at $+40 \mathrm{mV}$ holding potential in the presence of $\mathrm{Mg}^{2+}$. In some experiments $(n=8)$ the mean $10-90 \%$ rise time of NMDA PSCs at $+40 \mathrm{mV}$ holding potential was determined after addition of DNQX $(10 \mu \mathrm{M})$ to the extracellular solution. Addition of DNQX did not significantly affect the $10-90 \%$ rise times of PSCs at $+40 \mathrm{mV}$ holding potential, because these PSCs are largely mediated by NMDA receptors (Fig. 7D). Therefore we also included the mean $10-90 \%$ rise times of PSCs at $+40 \mathrm{mV}$ holding potential, which were obtained without blocking AMPA receptors by DNQX $(n=25)$. As shown in Figure $7 E$, the $10-90 \%$ rise time of NMDA PSCs was independent of the percentage of silent synapses present in a given experiment. For recordings containing $0-10 \%$ silent synapses, the mean rise time of NMDA PSCs was $9.9 \pm 0.6 \mathrm{msec}(n=5)$ and did not significantly differ from the mean rise time of NMDA PSCs in recordings containing $90-100 \%$ silent synapses $(9.8 \pm 0.4 \mathrm{msec}$, $n=6)$. These results thus do not support that the glutamate concentration is lower in the synaptic cleft of silent synapses.

Furthermore, we used the rapidly dissociating NMDA receptor antagonist D-AA to compare glutamate concentrations in silent and functional synapses. D-AA has been used to estimate the glutamate concentration in the synaptic cleft of functional hippocampal synapses (1.1 mM; Clements et al., 1992). D-AA is displaced at functional synapses by presynaptically released glutamate in a glutamate concentration-dependent manner. At its $K_{\mathrm{D}}(30 \mu \mathrm{M})$ D-AA blocks NMDA PSCs of functional synapses by $\sim 50 \%$, whereas a $75 \%$ block would be expected if no displacement of D-AA occurs (at glutamate concentrations $\leq 100 \mu \mathrm{M}$;
Clements et al., 1992). Assuming a reduced glutamate concentration $(\leq 100 \mu \mathrm{M})$ in the synaptic cleft of silent synapses, an increased block of NMDA PSCs by D-AA compared with functional synapses would be expected. Again, we first estimated the percentage of silent synapses present for each recording from the failure rates (112 stimuli at $0.2 \mathrm{~Hz}$ ) obtained at $-80 \mathrm{mV}$ and at $+40 \mathrm{mV}$ holding potential in the presence of $\mathrm{Mg}^{2+}$ at P3-P4 (Fig. 8). Then, $30 \mu \mathrm{m}$ D-AA was applied at $+40 \mathrm{mV}$ holding potential, and the resulting block of the NMDA receptor-mediated component of the PSC (amplitude $30 \mathrm{msec}$ after stimulus) was determined. As shown in Figure $8 D$, we found no correlation between the amount of block by D-AA and the percentage of silent synapses present. In recordings containing 20-40\% silent synapses the mean block of the NMDA receptor-mediated component of the PSCs by D-AA was $49 \pm 6 \%(n=4)$ and did not significantly differ from the mean block in recordings containing $80-100 \%$ silent synapses $(54 \pm 4 \%, n=8)$. These results again do not support a lower glutamate concentration in the synaptic cleft of silent synapses.

In conclusion, we present evidence for the existence of silent synapses in the neonatal visual cortex, which seem to disappear rapidly during postnatal development. These silent synapses appear to be postsynaptically silent, i.e., contain no or nonf unctional AMPA receptors, because no difference in glutamate concentration was observed compared with functional synapses. Conversion of silent synapses to functional ones thus suggests a postsynaptic expression of synaptic plasticity.

\section{DISCUSSION}

In the present study we demonstrate the existence of so-called silent synapses in the neonatal rat visual cortex. The properties of silent synapses have been studied mainly in the developing hippocampus (Isaac et al., 1995; Liao et al., 1995; Durand et al., 1996). In the presence of $\mathrm{Mg}^{2+}$ silent synapses typically show exclusively NMDA receptor-mediated transmission at depolarized membrane potential, whereas AMPA receptor-mediated transmission is not detectable at hyperpolarized membrane potential. Thus, they are functionally silent at resting membrane potential because of the voltage-dependent blockade of NMDA receptors by $\mathrm{Mg}^{2+}$. In the neonatal visual cortex we found strikingly higher failure rates of glutamatergic synapses at hyperpolarized compared with depolarized membrane potentials. Assuming a colocalization of AMPA and NMDA receptors at functional synapses (Bekkers and Stevens, 1989), failure rates at hyperpolarized and depolarized membrane potentials should be equal. Thus, the above result suggests the presence of silent synapses exhibiting only NMDA receptor-mediated transmission (Liao et al., 1995; Wu et al., 1996; Isaac et al., 1997). Furthermore the existence of silent synapses in the visual cortex was directly confirmed by observing synapses that showed purely NMDA receptor-mediated synaptic transmission at depolarized membrane potential and no AMPA receptor-mediated transmission at hyperpolarized potentials (see Fig. 3). In the immature somatosensory cortex Isaac et al. (1997) studied the properties of thalamocortical synapses and also demonstrated the presence of silent synapses in the neocortex. However, in layer V/VI pyramidal neurons of the visual cortex the vast majority of glutamatergic synapses arises from intracortical connections (DeFelipe and Fariñas, 1992; Kageyama and Robertson, 1993), suggesting that the majority of synapses studied in this report represent intracortical synapses. 
A

\section{Holding Potential}

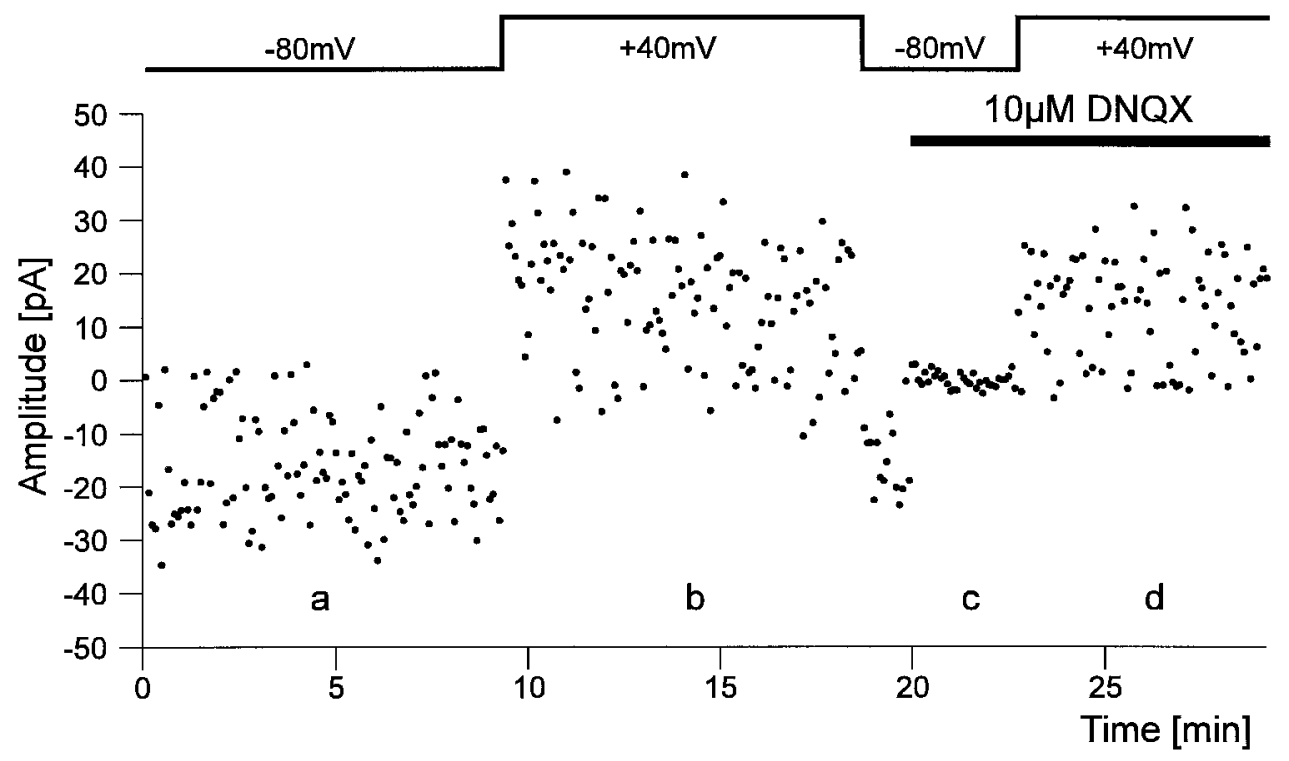

B

a

b

C

d
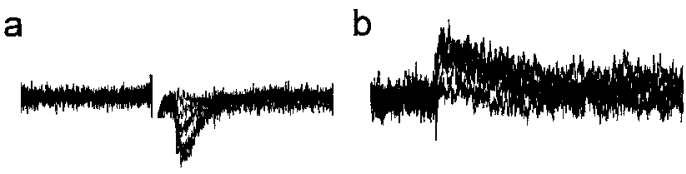

C

a

b

c

d
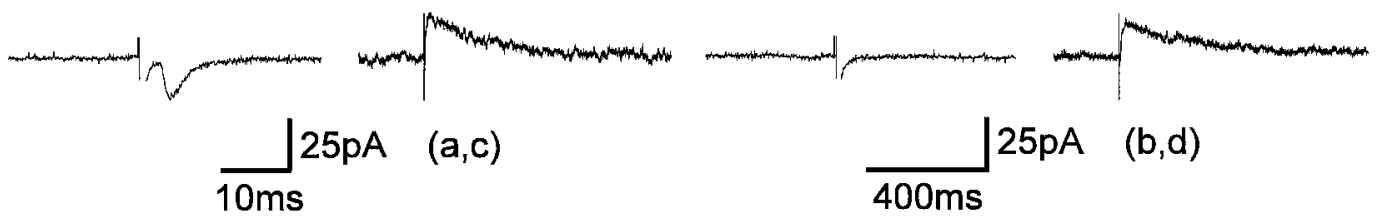

D

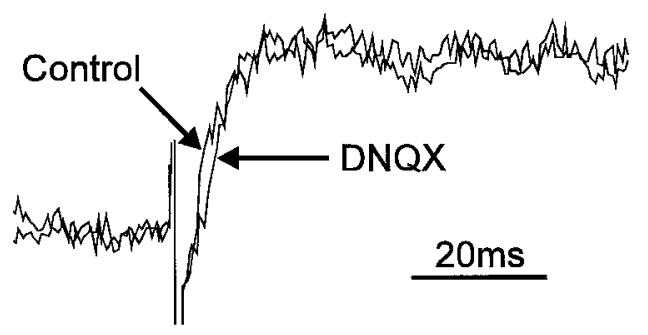

E

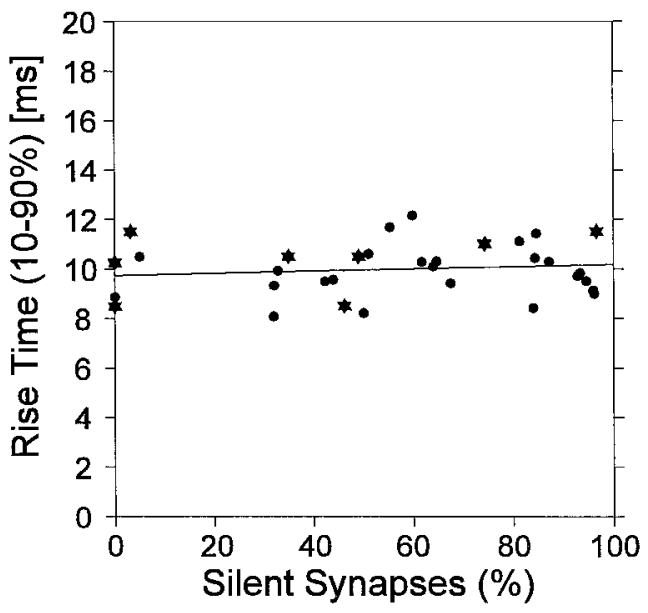

Figure 7. NMDA PSC rise times do not differ between silent and functional synapses. $A$, Individual response amplitudes recorded at $-80 \mathrm{mV}$ holding potential and at $+40 \mathrm{mV}$ holding potential. The failure rates obtained from this part of the experiment were used to calculate the proportion of silent synapses present. After application of DNQX, block of AMPA receptors was confirmed at $-80 \mathrm{mV}$ holding potential, and NMDA PSCs were recorded at $+40 \mathrm{mV}$ holding potential. $B$, Eight superimposed individual traces recorded at the positions indicated in $A$ at $-80 \mathrm{mV}$ holding potential $(a, c)$ and at $+40 \mathrm{mV}$ holding potential $(b, d)$. $C$, Average currents corresponding to the individual traces shown in $B$. $D$, Application of $10 \mu \mathrm{M}$ DNQX did not significantly change the rise time of PSCs recorded at $+40 \mathrm{mV}$ holding potential. $E$, The rise times (10-90\%) of PSCs recorded at $+40 \mathrm{mV}$ holding potential in the absence (circles) or presence (asterisks) of DNQX did not depend on the percentage of silent synapses present in a given experiment. 

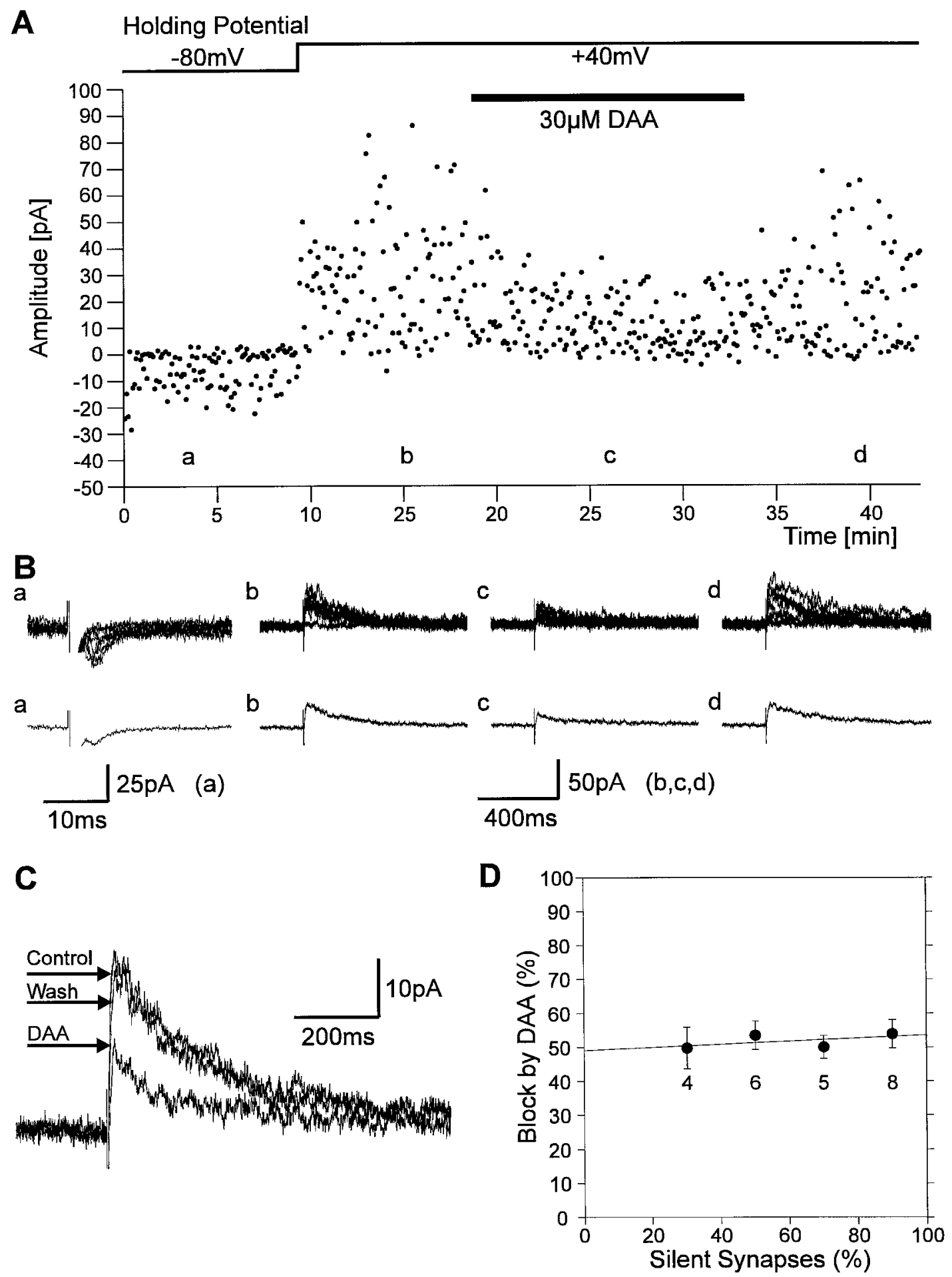

Figure 8. Block of NMDA PSCs by D-AA does not differ between silent and functional synapses. $A$, Individual response amplitudes recorded at -80 $\mathrm{mV}$ holding potential and at $+40 \mathrm{mV}$ holding potential. The failure rates obtained from this part of the experiment were used to calculate the proportion of silent synapses present $(68 \%)$. After application of D-AA the amount of blockade of PSCs at $+40 \mathrm{mV}$ holding potential was determined. $B$, Eight superimposed individual traces (top panel) and corresponding average currents (bottom panel) recorded at the positions indicated in $A$ at $-80 \mathrm{mV}$ holding potential $(a)$ and at $+40 \mathrm{mV}$ holding potential $(b, c, d)$. $C$, Superimposed average PSCs recorded at $+40 \mathrm{mV}$ holding potential before application of D-AA (Control), during application $(D A A)$, and after washout of the antagonist (Wash). $D$, The mean amount of blockade of PSCs at $+40 \mathrm{mV}$ holding potential by D-AA was not dependent on the percentage of silent synapses. Error bars represent SEM; $n$ is indicated below mean values.

The molecular mechanisms underlying silent synapses are debated controversially (Kullmann and Siegelbaum, 1995; Malenka and Nicoll, 1997; Kullmann and Asztely, 1998). The phenomenon of exclusively NMDA receptor-mediated transmission can be explained entirely postsynaptically. At silent synapses AMPA receptors either might be in a nonfunctional state or might not occur in the postsynaptic membrane (Isaac et al., 1995, 1997; Liao et al., 1995; Durand et al., 1996; Wu et al., 1996). Alternatively, 
presynaptic reasons can account for the existence of silent synapses. Because NMDA receptors show a much higher affinity for glutamate than AMPA receptors (Patneau and Mayer, 1990; Hestrin, 1992), a low concentration of glutamate in the synaptic cleft might selectively activate NMDA receptors without eliciting a detectable AMPA receptor-mediated response. At silent synapses vesicles might release a much smaller amount of glutamate, thus leading to a much lower glutamate concentration compared with functional synapses. A low concentration of glutamate could also be provided by spillover of glutamate from adjacent functional synapses on a neighboring neuron (Kullmann et al., 1996; Asztely et al., 1997; Barbour and Häusser, 1997; Kullmann and Asztely, 1998). These alternative hypotheses differ markedly in the postulated concentration of glutamate in the synaptic cleft and could be distinguished by examining the synaptic glutamate concentration at silent and functional synapses.

Direct measurements of synaptic glutamate concentrations are impeded by the small size of the synaptic cleft. However, glutamate concentrations can be estimated from the properties of NMDA PSCs. We examined two properties of NMDA PSCs that are dependent on glutamate concentration. First, the rise times of NMDA receptor-mediated currents are strongly dependent on the concentration of glutamate at concentrations $<50 \mu \mathrm{M}$ (Clements and Westbrook, 1991). Besides the agonist concentration theoretically only $\beta$ could also be a rate-limiting step; however, all calculated or measured $\beta$-values and all mathematical models exclude $\beta$ as a factor that determines the rise time of the synaptic current independent of agonist concentration (Dudel et al., 1992; Heckmann et al., 1996; Colquhoun et al., 1997). Thus, we compared the rise times of NMDA PSCs at functional and silent synapses. We found no significant differences in NMDA PSC rise times, suggesting that the glutamate concentration at silent synapses reaches at least $50 \mu \mathrm{M}$. Second, the selective NMDA receptor antagonist D-AA can be used to estimate the synaptic glutamate concentration (Clements et al., 1992; Clements, 1996). Because of its fast unbinding rate, D-AA is displaced from the NMDA receptors by synaptically released glutamate in a glutamate concentration-dependent manner. Thus, application of $\mathrm{D}-\mathrm{AA}$ results in a glutamate concentration-dependent blockade of NMDA PSCs. Assuming two binding sites for D-AA at NMDA receptors, at its $K_{\mathrm{D}}(30 \mu \mathrm{M})$ D-AA should block NMDA PSCs by $75 \%$ if no displacement of D-AA occurs. At glutamate concentrations $>100 \mu \mathrm{M}$, displacement of D-AA leads to a reduction of D-AA block of NMDA PSCs. From the considerable displacement of D-AA leading to only $\sim 50 \%$ blockade of NMDA PSCs at functional synapses, Clements et al. (1992) estimated the concentration of glutamate to reach $1.1 \mathrm{~mm}$. Thus, at low glutamate concentrations $30 \mu \mathrm{M}$ D-AA is expected to block NMDA PSCs by $75 \%$, whereas a significantly weaker blockade is expected at higher concentrations. We found a blockade of NMDA PSCs of $\sim 50 \%$ that was independent on the fraction of silent synapses present, thus suggesting that glutamate concentrations do not differ between functional and silent synapses. Using a similar experimental approach, Tong and Jahr (1994) demonstrated by studying evoked autaptic NMDA PSCs in cultured hippocampal neurons that drugs that alter presynaptic release lead to a significant change in the inhibition of NMDA PSCs by a fast unbinding NMDA receptor antagonist.

The above results suggest that synaptic glutamate concentrations do not differ between silent and functional synapses, supporting that silent synapses contain either no or nonfunctional AMPA receptors. Alternative explanations assuming a lower glutamate concentration at silent synapses are not supported by our findings. However, even glutamate concentrations of up to $200 \mu \mathrm{M}$ may be insufficient to elicit detectable AMPA receptormediated PSCs. At $200 \mu \mathrm{M} \sim 20 \%$ of the AMPA receptors mediating the AMPA PSC at functional synapses (at $1.1 \mathrm{~mm}$ glutamate) might be activated, as estimated from the dose-response relationship of AMPA receptors (Hestrin, 1992). Thus, a small window of glutamate concentrations $(100-200 \mu \mathrm{M})$ remains at which the properties of NMDA PSCs would not differ compared with functional synapses and at which no detectable AMPA PSC would be elicited. However, spillover of glutamate from adjacent functional synapses should lead to a wide range of glutamate concentrations (down to $5 \mu \mathrm{M}$ ) that activate NMDA receptors sufficiently to detect a NMDA PSC. Thus, if spillover underlies silent synapses at least in a part of the silent synapses, the glutamate concentration-dependent properties of NMDA PSCs should differ from those of functional synapses.

A typical property of silent synapses is that they can be converted to functional synapses. Such a conversion is indicated by the appearance of AMPA PSCs after an LTP induction protocol (Isaac et al., 1995, 1997; Liao et al., 1995; Durand et al., 1996). In the visual cortex we could convert silent synapses to functional ones by pairing presynaptic stimulation and postsynaptic depolarization. This conversion was strictly dependent on NMDA receptor activation. After the pairing protocol we observed a large increase in the success rate of AMPA PSCs, whereas the success rate of NMDA PSCs did not change. As discussed above, silent synapses appear to be postsynaptically silent; i.e., they do not contain functional AMPA receptors. Thus, this selective increase in the success rates of AMPA PSCs suggests a postsynaptic expression of synaptic plasticity, i.e., a modification of AMPA receptors making them functional. This could occur by phosphorylation of membrane-incorporated AMPA receptors, leading to changes in their biophysical properties. There is some evidence that activation of calcium-calmodulin-dependent protein kinase II (CaMKII) by NMDA receptor-mediated $\mathrm{Ca}^{2+}$ influx might mediate AMPA receptor modification (Shirke and Malinow, 1997). Expression of constitutively active CaMKII in frog optic tectum neurons led to an acceleration of the developmental disappearance of silent synapses (Wu et al., 1996). Moreover, phosphorylation of AMPA receptors by CaMKII after LTP induction has been demonstrated by Barria et al. (1997). Alternatively, other postsynaptic mechanisms of AMPA receptor modification are conceivable, e.g., a fast insertion of a cluster of AMPA receptors into the postsynaptic membrane (Malinow, 1994) or a fast accumulation of extrasynaptic AMPA receptors in the subsynaptic membrane.

In the visual cortex we observed a strong developmental decline in the incidence of silent synapses during the first two postnatal weeks, as estimated from differences in failure rates of AMPA and NMDA PSCs. Because silent synapses are observed during the early period of synaptogenesis (Blue and Parnavelas, 1983) it may be suggested that after the initial formation of glutamatergic synapses a considerable portion exhibits only NMDA receptor-mediated transmission. During further development silent synapses might be converted in functional ones, if activation of NMDA receptors by synchronous presynaptic and postsynaptic activity occurs.

In the visual system it has been proposed that mechanisms analogous to NMDA receptor-dependent LTP underlie the modification of synaptic circuitry by experience during the critical period (Goodman and Shatz, 1993; Singer, 1995; Katz and Shatz, 
1996). The conversion of silent synapses in functional ones appears to be a major mechanism of LTP-like synaptic plasticity in the neonatal neocortex, as suggested by the close correlation of the disappearance of silent synapses and the loss of the ability to generate LTP (Crair and Malenka, 1995; Isaac 1997). Thus, the NMDA receptor-dependent conversion of silent synapses to functional ones might be one cellular mechanism involved in activity-dependent refinement of synaptic connections. Developmental refinement processes might occur much more effectively by a process that can rapidly add new functional elements than by a process that slowly changes the efficacy of existing synapses.

\section{REFERENCES}

Artola A, Singer W (1987) Long-term potentiation and NMDA receptors in rat visual cortex. Nature 330:649-652.

Asztely F, Erdemli G, Kullmann DM (1997) Extrasynaptic glutamate spillover in the hippocampus: dependence on temperature and the role of active glutamate uptake. Neuron 18:281-293.

Barbour B, Häusser M (1997) Intersynaptic diffusion of neurotransmitter. Trends Neurosci 20:377-384.

Barria A, Muller D, Derkach V, Griffith LC, Soderling TR (1997) Regulatory phosphorylation of AMPA-type glutamate receptors by CaMKII during long-term potentiation. Science 276:2042-2045.

Bear MF, Cooper LN, Ebner FF (1987) A physiological basis for a theory of synaptic modification. Science 237:42-48.

Bear MF, Press WA, Connors BW (1992) Long-term potentiation in slices of kitten visual cortex and the effects of NMDA receptor blockade. J Neurophysiol 67:841-851.

Bekkers JM, Stevens CF (1989) NMDA and non-NMDA receptors are co-localized at individual excitatory synapses in cultured rat hippocampus. Nature 341:230-233.

Blanton MG, Lo Turco JJ, Kriegstein AR (1989) Whole cell recording from neurons in slices of reptilian and mammalian cerebral cortex. J Neurosci Methods 30:203-210.

Blue ME, Parnavelas JG (1983) The formation and maturation of synapses in the visual cortex of the rat. II. Qantitative analysis. J Neurocytol 12:697-712.

Clements JD (1996) Transmitter timecourse in the synaptic cleft: its role in central synaptic function. Trends Neurosci 19:163-171.

Clements JD, Westbrook GL (1991) Activation kinetics reveal the number of glutamate and glycine binding sites on the $N$-methyl-D-aspartate receptor. Neuron 7:605-613.

Clements JD, Lester RAJ, Tong G, Jahr CE, Westbrook GL (1992) The time course of glutamate in the synaptic cleft. Science 258:1498-1501.

Colquhoun D, Hawkes AG, Merlushkin A, Edmonds B (1997) Properties of single ion channel currents elicited by a pulse of agonist concentration or voltage. Philos Trans R Soc Lond A 355:1743-1786.

Crair MC, Malenka RC (1995) A critical period for long-term potentiation at thalamocortical synapses. Nature 375:325-328.

DeFelipe J, Fariñas I (1992) The pyramidal neuron of the cerebral cortex: morphological and chemical characteristics of the synaptic inputs. Prog Neurobiol 39:563-607.

Dudel J, Franke C, Hatt H (1992) Rapid activation and desensitization of transmitter-liganded receptor channels by pulses of agonists. In: Ion channels, Vol 3 (Narahashi T, ed), pp 207-260. New York: Plenum.

Durand GM, Kovalchuk Y, Konnerth A (1996) Long-term potentiation and functional synapse induction in developing hippocampus. Nature 381:71-75.

Fox K, Daw NW (1993) Do NMDA receptors have a critical function in visual cortical plasticity? Trends Neurosci 16:116-122.

Goodman CS, Shatz CJ (1993) Developmental mechanisms that gener- ate precise patterns of neuronal connectivity. Cell 72/Neuron 10[Suppl]:77-98.

Heckmann M, Bufler J, Franke C, Dudel J (1996) Kinetics of Homomeric GluR6 glutamate receptor channels. Biophys J 71:1743-1750.

Hestrin S (1992) Activation and desensitization of glutamate-activated channels mediating fast excitatory synaptic currents in the visual cortex. Neuron 9:991-999.

Isaac JTR, Nicoll RA, Malenka RC (1995) Evidence for silent synapses: implications for the expression of LTP. Neuron 15:427-434.

Isaac JTR, Crair MC, Nicoll RA, Malenka RC (1997) Silent synapses during development of thalamocortical inputs. Neuron 18:269-280.

Kageyama GH, Robertson RT (1993) Development of geniculocortical projections to visual cortex in rat: evidence for early ingrowth and synaptogenesis. J Comp Neurol 335:123-148.

Kasper EM, Larkman AU, Lübke J, Blakemore C (1994a) Pyramidal neurons in layer 5 of the rat visual cortex. II. Development of electrophysiological properties. J Comp Neurol 339:475-494.

Kasper EM, Lübke J, Larkman AU, Blakemore C (1994b) Pyramidal neurons in layer 5 of the rat visual cortex. III. Differential maturation of axon targeting, dendritic morphology, and electrophysiological properties. J Comp Neurol 339:495-518.

Katz LC, Shatz CJ (1996) Synaptic activity and the construction of cortical circuits. Science 274:1133-1138.

Kimura F, Otsu Y, Tsumoto T (1997) Presynaptically silent synapses: spontaneously active terminals without stimulus-evoked release demonstrated in cortical autapses. J Neurophysiol 77:2805-2815.

Kirkwood A, Lee H-K, Bear MF (1995) Co-regulation of long-term potentiation and experience-dependent synaptic plasticity in visual cortex by age and experience. Nature 375:328-331.

Kullmann DM, Asztely F (1998) Extrasynaptic glutamate spillover in the hippocampus: evidence and implications. Trends Neurosci 21:8-14.

Kullmann DM, Siegelbaum SA (1995) The site of expression of NMDA receptor-dependent LTP: new fuel for an old fire. Neuron 15:997-1002.

Kullmann DM, Erdemli G, Asztely F (1996) LTP of AMPA and NMDA receptor-mediated signals: evidence for presynaptic expression and extrasynaptic glutamate spill-over. Neuron 17:461-474.

Liao D, Hessler NA, Malinow R (1995) Activation of postsynaptically silent synapses during pairing-induced LTP in CA1 region of hippocampal slice. Nature 375:400-404.

Malenka RC, Nicoll RA (1997) Silent synapses speak up. Neuron 19:473-476.

Malinow R (1991) Transmission between pairs of hippocampal slice neurons: quantal levels, oscillations, and LTP. Science 252:722-724.

Malinow R (1994) LTP: desperately seeking resolution. Science 266:1195-1196.

McBain CJ, Mayer ML (1994) N-Methyl-D-aspartic acid receptor structure and function. Physiol Rev 74:723-760.

Patneau DK, Mayer ML (1990) Structure-activity relationships for amino acid transmitter candidates acting at $N$-methyl-D-aspartate and quisqualate receptors. J Neurosci 10:2385-2399.

Shirke AM, Malinow R (1997) Mechanisms of potentiation by calciumcalmodulin kinase II of postsynaptic sensitivity in rat hippocampal CA1 neurons. J Neurophysiol 78:2682-2692.

Singer W (1995) Development and plasticity of cortical processing architectures. Science 270:758-764.

Stevens CF, Wang Y (1994) Changes in reliability of synaptic function as a mechanism for plasticity. Nature 371:704-707.

Tong G, Jahr CE (1994) Multivesicular release from excitatory synapses of cultured hippocampal neurons. Neuron 12:51-59.

Tsumoto T (1992) Long-term potentiation and long-term depression in the neocortex. Prog Neurobiol 39:209-228.

Wu G-Y, Malinow R, Cline HT (1996) Maturation of a central glutamatergic synapse. Science 274:972-976. 